\title{
Jewish Immigrant Settlement Patterns in Manchester and Leeds 1881
}

Authors: Dr Laura Vaughan, Professor Alan Penn

Contact:

Dr Laura Vaughan

Bartlett School of Graduate Studies

University College London

London, WC1E 6BT

l.vaughan@ucl.ac.uk

\begin{abstract}
This paper examines the $19^{\text {th }}$ century Jewish immigrant quarters of Manchester and Leeds. It uses original census data to look at the entire population of the two areas of initial settlement. Analysis of family and kin structure, occupations of head of household, country of origin and length of time in the country as well as analysis of the settlement patterns at the street-level are combined to examine the phenomenon of immigrant clustering. We conclude that the complex social and economic processes involved in the establishment of a new migrant community in its host society result in spatial clustering and that the spatial clustering in close proximity to sources of income is critical in enabling future integration of the immigrant group.
\end{abstract}

\section{Acknowledgements}

The authors are indebted to the Engineering and Physical Sciences Research Council, which funded a PhD studentship in support of this research. The authors thank Professor Bill Williams and Rosalyn Livshin and the Manchester Jewish Museum for permission to use their data on Jewish individuals in Manchester, 1881 and the location of Jewish businesses, 1878-1884. The authors thank Murray Freedman for permission to use his data on Jewish individuals in Leeds 1881. Any interpretation of the above data is solely the responsibility of the authors. The other principal source of data used here is the Census Enumerators' Books of the 1881 Census for Great Britain, computerised by the Genealogical Society of Utah, Federation of Family History Societies and reformatted by The Data Archive, University of Essex. We acknowledge the use of this data set in our work. We would like to express our gratitude to the Data Archive, which processed the files for Manchester and Leeds out of sequence. Thank-you also to Dr Anne Kershen, Director of the Centre for the Study of Migration at Queen Mary College, London, for her kind advice. We would also like to thank the anonymous reviewers of an early draft of this paper, for their thoughtful advice and guidance.

This is a preprint of an Article accepted for publication in Urban Studies $\square$ 2005-6. 


\section{Introduction}

Numerous accounts of 19th century slums show the negative perceptions associated with clusters of ethnic minorities (Mayne, 1993). Newspapers were full of outcries at the influx of 'foreigners' creating 'colonies of disorder and sin' (op cit, p. 158). Wirth in 'The Ghetto' (1928) notes that the voluntary European and North American immigrant quarter was typically located at the edge of the central business district, and he emphasises the economic importance of this location. At the same time Wirth suggests that from a social point of view, the immigrant quarter was typically a functionally distinct district, cut-off from the life of the rest of the city. More recent research into historical immigrant settlement has shown that there is a more subtle set of relations between immigrants and the host society than suggested by Wirth - with economic transactions consistently breaking through the perceived barrier of the immigrant quarter (Godley, 2001 and White, 2003). Studies of contemporary immigrant groups support these ideas and suggest that immigrants benefit from clustering as this leads to self-help, the creation of niche economies and ultimately is more likely to bring about economic independence (see for example Nasser, 2004). The clustering of immigrants is central to popular debate today, where the lack of immigrant integration, apparently made manifest in spatial aggregation, is seen as a critical part of the inner city problem! .

Johnston et al (2002) maintain that clustering amongst some groups, such as South Asians, is to maintain cultural security and to avoid contact with "what they see as a prejudiced host society" (op cit, p. 609) although the desire to sustain strong rules of endogamy, particularly amongst Moslems, could be put forward as an equally viable explanation. Robinson (1984) suggested a term for this: "encapsulation", meaning the existence of a group in spatial concentration in a "sort of social bubble", distinct from the host society, speaking a vernacular language, with their own modes of dress and rules of marriage. Aftab et al (2005) propose that the larger-scale spatial outcome of this is "exclusive co-presence", namely that the public spaces and streets around the housing estates of the East End of London are utilised by the encapsulated Bangladeshi population to maintain close kinship ties and that in particular, the local high street of Brick Lane constitutes a "community generating space", with high levels of male social interaction taking place in the street, enabled by its local spatial importance (integration).

Recent studies have found similar settlement patterns for contemporary immigrants. Sultan Khan (2003) has studied the use of public space by people of Pakistani origin in Southall, west London, and found that the high street has been adapted for the use of this minority community in its economic activities, through a replication of behaviour patterns from the home country (despite a considerable lapse of time since migration). She also found that the realisation of community in public space enables the perpetuation of the roles of the various members of the community in preserving its traditional social rules. Such patterns of behaviour amongst relatively established immigrants are explained by Peach (1998), who has found that for some ethnic groups there is a continuing choice of clustering (albeit in a more dispersed pattern) in order to create opportunities for endogamy and sufficient population for religious and cultural institutions to thrive. Similarly, Waterman and Kosmin (1987) note the continuation of clustering amongst British Jews (in many cases third or fourth generation descendants of immigrants), yet show that they avoid any degree of spatial segregation which might isolate them from the benefits of fully functional integration into society.

These contemporary studies of immigrant clustering point to a need to understand why spatial clustering is important and how the pattern of immigrant settlement contributes to this phenomenon. Classic texts such as 'The Death and Life of Great American Cities' (Jacobs, 1961), 'Family and Kinship in East London' (Young and Willmott, 1962) and 'The Urban Villagers' (Gans, 1962), highlight the importance of the street as the point of social engagement within a community and between locals and strangers (indeed Gans describes an immigrant quarter in his case). These ideas lie at the background to the research presented here ${ }^{2}$, which stemmed from a hypothesis that given the right conditions, immigrant communities can utilise their spatial location to strengthen internal ties for self-support as well as to start to create external ties with their host society. This study has used a combination of traditional census data methods, which consider the entire population of the $19^{\text {th }}$ century Jewish immigrant quarters of Manchester and Leeds, with comparative data on the social, occupational and spatial distribution of the immigrant community and the local host community, and spatial analysis of the settlement patterns at the street-level, to examine the phenomenon of immigrant clustering. In order to take advantage of the spatial resolution with which the historical social and occupational data are

\footnotetext{
${ }^{1}$ A recent paper by John Eade (published in Kershen, 1997), reviewing the opposition to plans for a minaret in the East End of London, showed the vigorous hostility amongst the general public towards muezzin who call the Muslims to prayer - the Muslims were also accused of cutting themselves off from British life (and drowning out the sound of church bells).

${ }_{2}^{2}$ This research forms part of a PhD thesis in architecture, see Vaughan, 1999.
} 
available we made use of space syntax methods of spatial analysis. These allow the use of the street as the unit of analysis and so allow the researcher to consider the fine scale spatial structure of the open space of the city street pattern, the pattern which acted as the background to common experience and which generated the potential for the immigrant to engage with his or her home community, as well with the host community.

The study areas were the geographical districts of initial settlement by Jewish immigrants in Manchester and Leeds: Red Bank and Leylands - referred to from now on as the 'immigrant quarters'. In both cases, the entire population of the areas (not only Jewish immigrants, or Jewish households) was analysed in order to compare the situation of Jewish households with that of their neighbours. In both cases there was a plethora of historical and geographical evidence to indicate that both quarters had clearly defined boundaries. See e.g. Makepeace (1995, p. 1) and Freedman (1992, p. 26).

This paper starts with a description of the two cases of Manchester and Leeds in 1881. It then analyses data on family and social structure, occupation, followed by spatial analysis. The paper ends by drawing the three parts of the analysis together and a discussion of the nature of immigrant clusters and the importance of spatial location and form in creating the potential for immigrant integration. We suggest that those conditions include proximity to markets and places of employment as well as having a relatively permeable street network - one that enables a range of people of different types to mix with each other. We propose that under certain conditions spatial, social and occupational clustering can exert a positive effect on the process of migrant integration into a host economy through the stronger social, economic and informational support networks that it furnishes, even though this may involve a degree of segregation.

\section{Background to the cases}

Manchester and Leeds were the most important examples of Jewish settlement outside London in the late 19th century. Cities such as these were part of a process of urbanisation and industrialisation, which took place in England during the period considered here. The decision to study these two cities in particular is due to historians pointing out their importance as provincial settlements for migrants during this period (see e.g. Englander, 1994, p. 247 and Kershen, 1995, p. 39): both cities contained the largest clusters of Jewish settlement outside of London at that time. The census year of 1881 was chosen for the study cut-off date, since it marks the end of a period of growth in Jewish immigration during the 1860s and 1870 that was mainly due to economic privations in Eastern Europe (Williams 1985, p. 265), but is before the mass-migration from Eastern and Central Europe from 1882-3 onwards, which was a response to an increase in the persecution of Jews in these areas as well as to an economic crisis.

According to Williams (1985, p. 268), whilst a middle-class Jewish population had established settlements in the inner suburbs of Manchester by the middle of the 19th century, the expansion of East European immigrant settlement in Manchester in the 1860s and 1870s led to the emergence of the district of Red Bank - an area at the edge of the city's business district (fig. 1) - as an immigrant 'colony', with a distinctively poorer, more undernourished, unskilled and less skilled population than the existing established Jewish population of the city. He states that the Red Bank area became a 'classic slum', physically invisible: "self-contained and shielded from view by the lie of the land and a facade of shops and public buildings, socially barricaded by the railway and industries in the polluted valley of the Irk, and so neglected and ill-lit as to be in a state of 'perpetual midnight' " (op cit, p. 81). In patterns of employment, the immigrant Jews of Manchester were in many ways similar to Jews in other cities, where trades such as tailoring, slipper-making, glazing and jewellery predominated, although the importance of cotton trade in Manchester and the city's role as a centre of retail trades had an indirect impact on Jewish trades, as will be shown below. 


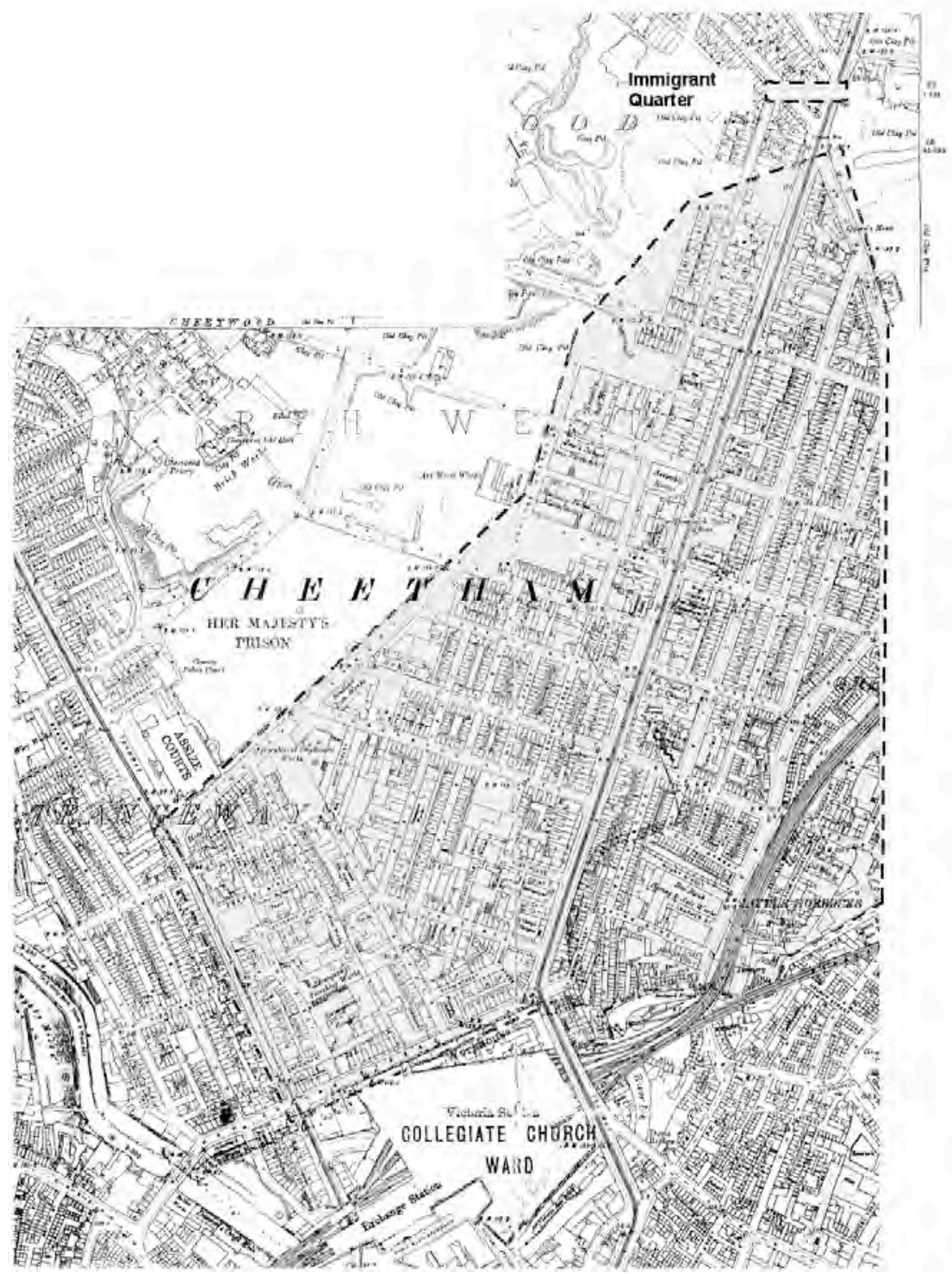

Fig. 1: Red Bank area and its surroundings, c 1881.

A similar influx of immigrants took place within the Leylands district of Leeds (fig. 2) although it had only a small core of Jewish inhabitants prior to the 1880s. In geographical terms, the area of Leeds remained relatively small and compact in the 19th century, in comparison with Manchester, and its outlying townships which only became part of the city in the early 20 th century. However by the mid-nineteenth century, Leeds had become a centre for the manufacturing industry, particularly for engineering and textiles. Kershen (1995) suggests that this helps explain the growth of immigration to the city at this time. 


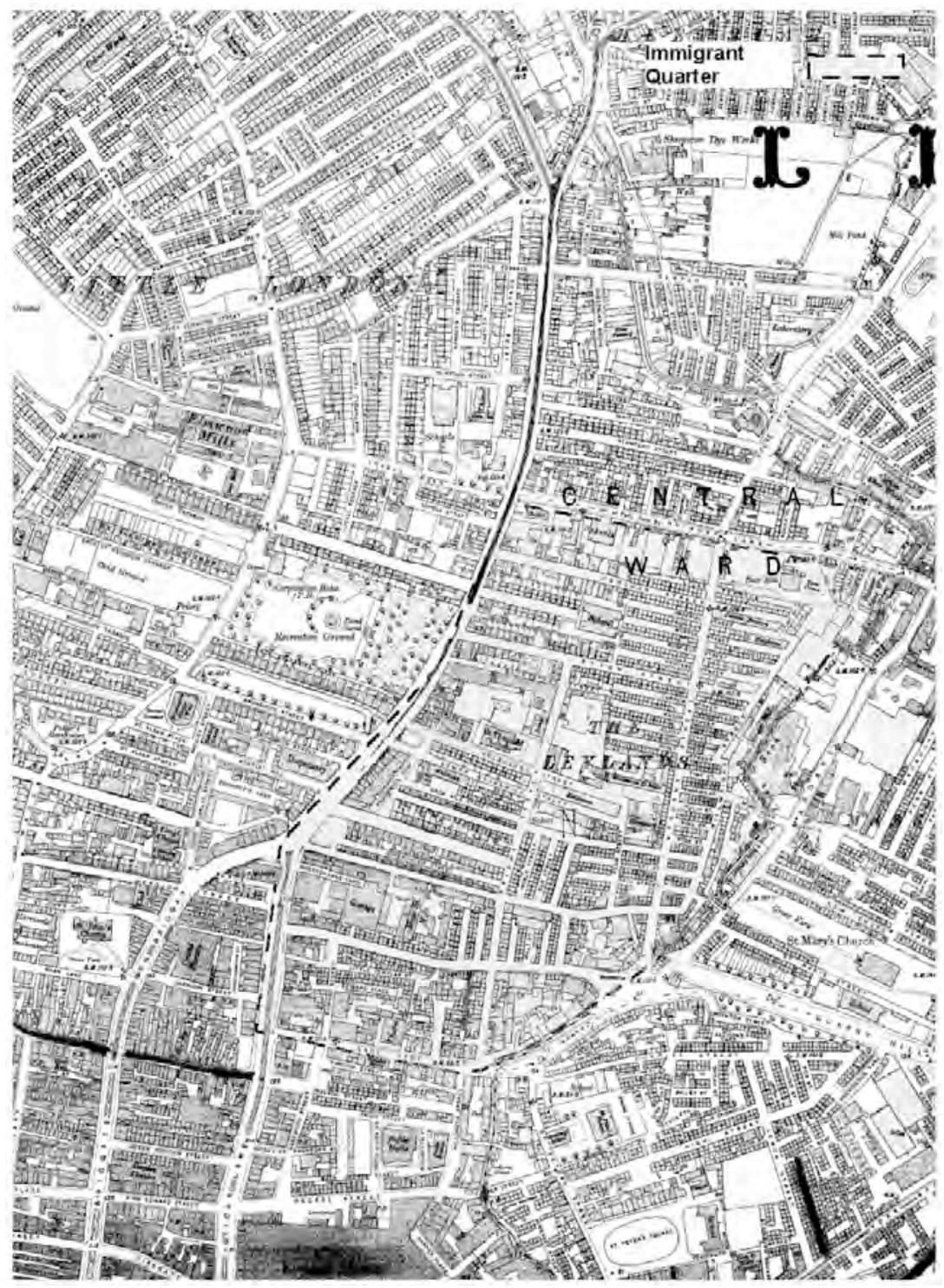

Fig. 2: Leylands and its surroundings, c 1881.

The primary data source on household structure, economic situation, and all other social data, were the original 1881 census records on individuals, provided by the Data Archive (1997). The research entailed extraction of records for the entire population of each of the immigrant quarters and analysing family, household, occupation and economic variables. The data were first summarised by household, then summarised by street. Jewish individuals were identified in the censuses from databases provided by Williams (1985) for Manchester and Freedman (1994) for Leeds ${ }^{3}$.

The Red Bank and Leylands districts became known as the immigrant quarters of Manchester and Leeds and these are the areas that are considered in detail in this study. The Jewish population of the two cities in 1881 was approximately 7,000 in Manchester and 2,900 in Leeds ${ }^{4}$. In the case of Leeds, most of the Jews were still located in the immigrant quarter at the time studied here. Williams (1985) shows that Manchester had a more established Jewish population than Leeds and the data collected for this research supports this, showing that the percentage of Jewish inhabitants in the immigrant quarters from all Jewish inhabitants was only $40 \%$ in

\footnotetext{
${ }^{3}$ Both Bill Williams and Murray Freedman employed similar methods for identifying Jewish inhabitants. They looked at the census records for the entire built-up areas of the cities in question, as well as some outlying settlements. They identified households that were likely to contain Jews through name (both names that are nearly always Jewish, such as Cohen and names of Germanic or East European form), occupation, and country of birth. After this, cross-referencing was made with other sources of communal records (such as synagogue membership lists and burial records) in order to verify whether the people in question were part of the established community or had a link to it. Both researchers point out that the lists are generally minimal lists, since questionable cases were eliminated. See Williams (1985), in the appendix on the maps and Freedman (1994), pp. 1-2.

${ }^{4}$ Source: Lipman (1990), p. 16 and Freedman (1992), p. 23.
} 
Manchester, whilst it was $80 \%$ in Leeds. However, both immigrant quarters had similar proportions of Jews to gentiles, at around $30 \%$ (see Table 1).

Table 1: Data on Jewish population numbers

Total number of Jews in Manchester 7745

$\begin{array}{ll}\text { Total population in Manchester } & 341414\end{array}$

Percentage of Jews from population in Manchester:

$341414-$

Total number of Jews in Red Bank: 3115

Total population in Red Bank:

Percentage of Jews in Red Bank from population of Red Bank:

9578

Percentage of Jews in Red Bank from population of Jews in Manchester

$32.50 \%$

$40.22 \%$

Total number of Jews in Leeds:

2937

309119

Percentage of Jews from population in Leeds:

$$
\begin{aligned}
2937 & - \\
309119 & - \\
& 0.95 \% \\
2371 & - \\
8515 & - \\
& 27.80 \% \\
& 80.73 \%
\end{aligned}
$$

Percentage of Jews in Leylands from population of Jews in Leeds

Sources for data: statistical databases provided by Williams (1985) and Freedman (1994)

A measure of the 'foreignness' of the immigrant quarters can be found by considering the percentage of Jewish heads of household born abroad - this was found to have been $83 \%$ in Manchester's Red Bank immigrant quarter, and 95\% in Leeds' Leylands immigrant quarter. In addition, the average age of the eldest child born in Britain was calculated to give a measure of how long Jewish immigrant families had been in the country. This was found to be 9.8 years on average in Manchester's Red Bank as compared to 6.3 years in Leeds' Leylands. This appears to confirm that Leeds as a more recent location for immigrant settlement, as indicated by the historical sources mentioned above.

The rate of endogamy (marriage within the 'tribe') was considered for each of the immigrant areas, considering whether immigrants were likely to marry others from the same region of origin, in order to measure the likelihood of the existence of familial support structures. Only immigrant families - defined as at least one head having been born abroad - were selected for this analysis. Table 2 shows that there was a much higher rate of endogamy amongst Jewish immigrants in comparison to gentiles.

Table 2: Comparison of Birthplace data for immigrants only (averages per area)

Percentage of Jewish heads with same birthplace as wife, Red Bank: Percentage of gentile heads with same birthplace as wife, Red Bank: Percentage of Jewish heads with same birthplace as wife, Leylands:

Percentage of gentile heads with same birthplace as wife, Leylands:

$$
\begin{aligned}
& 75 \% \\
& \quad 83 \% \\
& 43 \%
\end{aligned}
$$

Despite the fact that past historical research has provided evidence on the economic and social segregation of the Jewish immigrant community (e.g. Kershen, 1995 and Williams, 1985), the question of whether this has a precise spatial dimension is considered here for the first time: namely, whether the perception of the immigrant districts of Manchester and Leeds as being physically removed from the life of the city - as was indicated in the descriptions quoted above - was correct. The distinctiveness of the immigrant quarters is considered here from various aspects: poverty, higher rates of unemployment, lower economic status, patterns of employment as well as physical segregation.

\section{Analysis of Social Structure}

This analysis takes its definitions of class from various data in the 1881 census: first, data on the occupations of the individual heads or sole Jewish boarders and lodgers, which provided information on social class; second, the number of boarders or lodgers was used as another indication of class. In addition, the study collated data on the country of origin of heads, wives and boarders in comparison with the head of household, which provided information on the degree of co-dependence in households; the assumption being that if the country of origin was the same, this indicated a social tie above and beyond the religious connection. A guide by Culling (1996) was used identify obscure 19th occupations. 
The most common method used by historians for classifying social class is to use the occupations stated in the census to assign individuals to one of 5 classes ranging from I (professional) to V (unskilled). The main reason for using occupation as a source of information on social or economic class, rather than, for example, the number of domestic servants or employees, is that the latter are only applicable to a portion of the entire population, see Higgs (1996, p. 134-6). However, these standard methods tend to create a disproportionately large Class III (skilled). Another limitation is that depending on the timing of the census, the number of unemployed would differ due to the seasonal nature of immigrant work, and this would have an impact on the state of unemployment ${ }^{5}$ : Kershen (1995) for example, shows that the tailoring industry was both seasonal and irregular, "the employer of one year becoming employee for the next" (op cit, p. 10), meaning that there could be both downward and upward class mobility. Kershen also shows that there were few skilled craftsmen among the Jewish tailors; most were partly skilled. It was therefore logical to change the standard categorisation of tailors as belonging the middle class III and to downgrade all 'tailors' not entered as 'Master Tailor' or 'cutter' (the most highly rated and paid skill), from Class III (skilled) to Class IV (partly-skilled) ${ }^{6}$. Occupations were however upgraded a class if the census showed that the individual employed 3 or more people, and up two classes if over 25 were employed, as recommended by Higgs (op cit, p. 137).

Table 3 shows the class distribution for the entire population of the immigrant quarters of Red Bank and Leylands. In both cases the proportion of heads in the top two classes is very low for the population and this is an indication that the Red Bank and Leylands districts were distinctive as poor areas, as well as immigrant areas. It is striking to note that whilst in Manchester's Red Bank there is a similar proportion of skilled Jewish and Gentile inhabitants, there is a much lower proportion of skilled Jewish inhabitants in Leeds' Leylands. This difference can perhaps be related to this area containing a much higher proportion of new immigrants.

Table 3: Class Distribution for all heads of Household in immigrant quarters All Streets in Red Bank

I Professional
II Intermediate
III Skilled
IV Partly Skilled
V Unskilled

All Streets in Leylands

I Professional

II Intermediate

III Skilled

IV Partly Skilled

V Unskilled

Jewish Percentages $(\mathrm{n}=413)$
$1 \%$
$7 \%$
$46 \%$
$46 \%$
$1 \%$

Jewish Percentages $(\mathrm{n}=386)$

$1 \%$
$3 \%$
$23 \%$
$73 \%$
1

Gentile Percentages $(\mathrm{n}=1080)$
$3 \%$
$4 \%$
$48 \%$
$37 \%$
$8 \%$

Gentile Percentages $(\mathrm{n}=1256)$
$1 \%$
$4 \%$
$56 \%$
$30 \%$
$9 \%$

Table 4 shows the average household size of Jewish and gentile households within the immigrant quarters (domestic servants and visitors were excluded from the calculation of household size). The sharing of households is a standard indicator of poverty, particularly if coupled with overcrowding. It is evident that Jewish households were larger on average than their gentile counterparts within the immigrant quarters $(\mathrm{p}<.0001)$.

Table 4: Average household size within immigrant quarters Red Bank

Jewish Household size $(\mathrm{n}=413)$

5.9

Leylands

Jewish Household size $(n=386)$

5.9
Gentile Household size $(n=1080)$

4.9

Gentile Household size $(\mathrm{n}=1256)$

4.2

In order to isolate the cause of this finding, it was further checked (table 5) by looking at the number of households sharing dwellings with another identifiable family unit (as was done by Armstrong, 1972). The definition of sharing households was based on the listing of more than one household in the census records at a

\footnotetext{
${ }^{5}$ The 1881 census took place on 7 September 1880 (Kershen 1995, p. 171).

${ }^{6}$ Along the same lines, where boot makers are normally classified as Class III, a division in this study was made between a Boot Master (classified as class III, skilled) and Boot machinist, finisher, riveter or clicker [one who cuts out leather for boots), which were downgraded to class IV, partly-skilled. The same was done for individuals employed as a Cloth burler, drawer, dresser, dyer, finisher, fuller, presser, rag sorter, tenterer and weaver - all of which are partly-skilled cloth industry trades.
} 
single address.

Table 5: Average percentage of sharing households within immigrant quarters Red Bank

Jewish Households $(\mathrm{n}=413)$

$10.6 \%$

Leylands

Jewish Households $(\mathrm{n}=386)$

$15.5 \%$
Gentile Households $(\mathrm{n}=1080)$

$4.6 \%$

Gentile Households $(\mathrm{n}=1256)$

$2.4 \%$

In both cities many more of the Jewish households shared with other families then did the gentile households. It was also found that a high proportion of Jews (60-80\% in the Manchester and Leeds immigrant quarters, respectively) had boarders from the same country, suggesting that the immigrant households had a preference to let out rooms to people from the same region, not simply the same religion.

Table 6 shows the proportion of sharing households by social class. It shows a high rate of sharing within the immigrant quarters and that the greatest proportions of shared dwellings were in the bottom two classes. There is a higher rate of sharing in Class IV than in Class V, perhaps due to their living in larger, subdivided dwellings than was the case of Class V (see chapter 11 in Englander, 1988).

Table 6: Percentage of sharing households, Jewish families

Red Bank

$\begin{array}{rlccc}\text { I } & \text { II } & \text { III } & \text { IV } & \text { V } \\ 0 & 5 \% & 15 \% & 23 \% & 10 \% \\ \text { Leylands } & & & & \\ \text { I } & \text { II } & \text { III } & \text { IV } & \text { V } \\ 7 \% & 4 \% & 12 \% & 21 \% & 13 \%\end{array}$

\section{Analysis of Occupational Structure}

There is a commonly held notion that immigrants tend to specialise in particular occupations. J Smith writing in 18997: states: '...strange as it may appear, the immigrant's future is more or less determined by the sort of trade done at the town where he lands or arrives. He may become a tanner or a dyer in Hull, and have a different ambition from what he would have if he landed at, say Liverpool, Glasgow, or London.' Other reasons for occupational specialisation tend to range from immigrants bringing a skill with them, to their identifying a niche in the local market (see Godley, 2001), to their being excluded from some activities due to prejudice (Light and Bonacich, 1988) or the inappropriateness of some activities to the patterns of an immigrant group's religious life (such as the orthodox Jew's requirement to not work on the Jewish Sabbath).

Historical evidence on the Jews of Manchester suggests that all of these factors contributed to their concentration in a smaller number of industries than was the case with the host community. This section investigates how this occupational distinctiveness related to the Jewish pattern of settlement: was the occupational specialization more pronounced than among the host population? Were the indigenous poor also distinctive in their occupations? This section considers only the Manchester immigrant quarter, as Manchester was a larger and more established occupational base than Leeds, both for the Jewish population of the city and for the general population, and due to a more detailed database being available for this case.

The main sources of data here are the census data of 1881 and the annual business directories for Manchester, 1878-1884. In addition, the occupations of all males in Manchester were extracted from census summaries (HMG, 1883) to enable comparison between the immigrant quarter and the city overall. Census occupation entries were simplified in this case in order to enable comparison; for example, tailor, seamstress and finisher were all defined as 'tailor'. In all, 190 occupations amongst the Jewish inhabitants of Manchester (both within Red Bank and across the city) were found by this method, in contrast with 377 occupations amongst the general population of Manchester. This analysis only considered male occupations, since female occupations were frequently omitted from the census and are difficult to enumerate, particularly amongst Jewish individuals, since Jewish men (even more than their gentile counterparts) were unlikely to admit that their wives had to work (Kershen, 1995, p. 15).

Analysis of all occupations reported by Jewish heads of households showed that there was little overlap with the

\footnotetext{
${ }^{7}$ Quoted in Englander (1994, p. 112).
} 
most common male occupations city-wide (HMG, 1883). Taking for example the most common occupation for males in Manchester: "general labourer, stoker, mechanic, machine worker", $9 \%$ of all adult males for whom there were completed returns, this occupation does not appear at all amongst the most popular occupations for Red Bank Jews. Similar contrasts were found between Red Bank Jews and Red Bank gentiles. Table 7a shows that whilst almost $60 \%$ of Jewish males were in the 10 most common occupations amongst Jewish heads, only $8 \%$ of gentile heads had 'top-10' Jewish occupations. On the other hand, only $5 \%$ of Jewish males were in the 10 most common gentile occupations (Table $7 \mathrm{~b}$ ). Indeed, the gentile population was more diffuse in its choice of occupation, with only $21 \%$ of gentile males in the 'top- 10 ' of gentile occupations in Red Bank. Although seemingly $30 \%$ of Jewish heads were occupied in common gentile occupations, this is only because of the dominance of tailoring, which was $26 \%$ for Jewish heads, but only $2 \%$ for gentile heads. Taking account of the considerably higher number of gentile households (around 3 times the number of Jewish households), this finding suggests that there was little common work activity between the Jewish immigrants and their neighbours (although it should also be noted that there were fewer complete records on gentile occupations). Bearing in mind the nature of the Jewish occupations, it is likely that a larger-scale set of relationships must have developed to enable activities such as cabinet making, tailoring, let alone mercantile activities to take place. In other words, it seems that rather than establishing neighbourhood-level economic ties, the Jewish inhabitants of Red Bank must have developed links with individuals and companies elsewhere in the city, perhaps in this way enabling a more rapid economic integration than might otherwise have taken place.

Table 7a: Common Jewish occupations, Red Bank

\section{OCCUPATION}

1. Cabinet maker

2. Cap maker/manufacturer

3. Commission agent

4. Glazier

5. Jeweller or watchmaker

6. Merchant/shipping merchant

7. Pawnbroker

8. Tailor

9. Commercial traveller*

10. Waterproof maker

TOTAL
Jewish heads, lodgers/boarders, $n=436$

$1.1 \%$

$4.1 \%$

$1.4 \%$

$9.9 \%$

$3.7 \%$

$3.2 \%$

$0.7 \%$

$25.9 \%$

$7.1 \%$

$1.8 \%$

$\mathbf{5 8 . 9 \%}$
Gentile heads, lodger/boarders, $n=1174$ )

$1.0 \%$

$0.3 \%$

$0.3 \%$

$0.2 \%$

$0.3 \%$

$0.9 \%$

No cases

$2.6 \%$

$2.0 \%$

$0.3 \%$

$8.1 \%$

* Traveller refers to travelling salesman, and does not include the small number of hawkers or costermongers in the two groups. By 1881 the latter trades, which had been common amongst Jews in earlier censuses, was starting to become less common.

Table 7b: Common gentile occupations, Red Bank OCCUPATION

1. Fruiterer/greengrocer

2. Housekeeper

3. Joiner

4. Labourer

5. Boarding house keeper*

6. Printer/compositor

7. Publican ${ }^{\wedge}$

8. Salesman/shopkeeper

9. Tailor

10. Warehouseman

TOTAL

Jewish incidence (\% all J.
heads, lodgers/boarders,
$\mathbf{n = 4 3 6}$ )
$0.2 \%$
$1.1 \%$
$0.4 \%$
$0.2 \%$
$1.4 \%$
No cases
$0.4 \%$
$0.9 \%$
$25.9 \%$
$0.4 \%$
$\mathbf{3 1 . 2} \%$

Non-Jewish incidence (\% all

non-J. heads,

lodgers/boarders, $n=1174$ )

$1.8 \%$

$2.0 \%$

$2.4 \%$

$3.7 \%$

$2.2 \%$

$1.2 \%$

$2.0 \%$

$2.4 \%$

$1.9 \%$

$1.9 \%$

$21.7 \%$

* Includes lodging-house keepers and hotel keepers

$\wedge$ Includes restaurant keepers, beer-house keepers and beer sellers

Previous research into patterns of migration suggests that the reason for this occupational clustering is that immigrants tend to seek out people from the 'old country' for support when they arrive. Yet, fewer gentile households containing boarders or lodgers had an occupation in common with the head, when compared with Jewish households, even when only immigrant gentile households were isolated, see Table 8. 
Table 8

Rate of common occupations within sharing households, Red Bank (immigrant households only)

Jewish households in Red Bank

Gentile households in Red Bank

$39 \%$

$18 \%$

\section{Analysis of Spatial Structure}

The primary form of spatial analysis used in this study was space syntax (Hillier \& Hanson, 1984). The advantage of space syntax methods for studies of immigrant quarters is that they deal with the city at street scale, rather than the common method of aggregated areal studies (see Noble et al, 2000 and Ballas, 2004). In addition, a key aspect of space syntax methods is that they deal with the relationship between local to global properties of spatial structures (in this case, as in many others, entire cities were mapped and analysed). All these measures are independent of variables such as class, land values and land-use, so the relationship between urban form and social structure can be studied statistically, with each variable considered in turn. Moreover, small differences between neighbouring streets and their degree of inter-accessibility can be quantified precisely.

Space syntax methods have been developed for analysing spatial layouts in buildings and urban areas, modelling the relationship between spatial layout and how people use and move through cities. These methods are based on the theories advanced by Hillier and Hanson (1984), in which a primary property of the form of the urban grid is to privilege certain spaces over others for through movement. In this way it is suggested that the configuration of the urban grid itself is the main generator of patterns of movement. The key spatial unit related to in this theory is the 'axial line', the longest line of sight and access that defines each of the streets in the city. The layout of the urban grid is represented as a system of axial lines intersecting through all open public space, known as the 'axial map'.

The axial map is analysed by computer as a pattern of accessibility, measuring the relative distance of each part from the system as a whole, and then describing the system according to the distribution of accessibility; ranging from the most accessible, 'integrated', to the least accessible, 'segregated'. The numeric properties of the spatial system are laid out in a table, allowing the mathematical analysis of the relationship between the spatial properties and other numerically measurable properties of space use. The key measure of the axial map is the integration value. Global integration (or integration radius n) measures the degree to which each line in the map is present on the simplest (fewest changes of direction) routes to and from all other lines. A version of global integration, termed 'local integration' (or integration radius 3) restricts the measurement of routes from any line to only those lines that are up to three steps away from it. This measures the localised importance of a space for access within a particular part of a city area. The numeric properties are also represented graphically, by colouring up the axial lines in a spectrum of colours, assigning light grey to the least integrated lines, medium grey to the medium integration values, through to dark grey and black to the most integrated lines (or in a coloured map, in a spectrum from blue, through green, orange and yellow, to red).

Space Syntax research has applied these analysis techniques to a large number of settlements around the world, ranging from villages to cities as large as Santiago and Tokyo (see Hillier, Penn et al 1993, Hillier 1996). In all of these sites they have found a statistically significant $(\mathrm{p} \leq .05)$ correlation between movement rates and integration values, observing that movement consistently rises as streets become more integrated and that the relative range of movement does not change according to the time of day. In other words, these studies have proposed that a large proportion of movement in cities can be explained by the basic configuration pattern itself. In general, pedestrian movement tends to correlate with local movement and vehicular, with global. Some notable exceptions to this relationship include modern housing estates which normally do not correlate at all, or in some extreme cases, as the Alexandra Road estate at Swiss Cottage in London, the relationship has been found to be bifurcated (see 'Can Architecture Cause Social Malaise' in Hillier, 1996).

Historical Ordnance Survey maps covering the entire built up area of the two cities at the time (see e.g. the map edited by Makepeace, 1995) were used to draw axial maps for Manchester and Leeds. Table 9 shows one of the measures of segregation used: depth from the most 'integrated' - accessible - line in Manchester, (which was Oxford Street, in the city centre), averaged across the districts of the city. The results show that Red Bank, whilst relatively close to the city centre, was spatially cut off from it, and that its degree of segregation was found to be significantly ${ }^{8}$ higher than that for other residential districts close to the city centre, such as Salford and Moss Side.

\footnotetext{
${ }^{8}$ In all cases where 'significance' is indicated in the analysis, a statistical 't-test' was conducted on the data.
} 
Table 9: Mean axial depth from the most globally integrated line in Manchester, averaged by district

$\begin{array}{lcc}\text { District } & \text { Depth } \text { ^ }^{-} & \text {p-values from t-tests * } \\ \text { Manchester central } & 5.697 & >.9999 \\ \text { Chorlton } & 6.167 & .0312 \\ \text { Moss Side } & 6.237 & .0266 \\ \text { Salford } & 6.625 & .3393 \\ \text { Strangeways } & 7.926 & <.0001 \\ \text { Red-Bank } & 7.926 & <.0001 \\ \text { Cheetham } & 9.458 & <.0001 \\ \text { Broughton } & 10.375 & <.0001\end{array}$

${ }^{\wedge}$ The measure of depth considers the number of street turnings away from a chosen street or streets. The higher the number, the greater the 'depth'. * The $\mathrm{p}$-value is a measure of significance, only values lower than 0.05 indicate a significant difference between the average of the sample compared to the average for the population

Analysis of the local integration map for each of the cities (see figs. 3 and 4, which display the axial local integration for each of the cities), shows that the immigrant quarters were close to the spatial core of the cities, but only the main streets of the area were connected into the core and within the quarters were pockets of significantly lower integration. This suggests that the perception of the areas as being cut off from the life of the city is correct, yet also suggests that there was the potential for people with greater economic wherewithal to take advantage of their proximity to the jobs and markets of the city. Although other areas of spatial segregation existed in both cities, these tended to be in locations at the city edges (as is the typical pattern in European cities), and not in other inner-city areas.

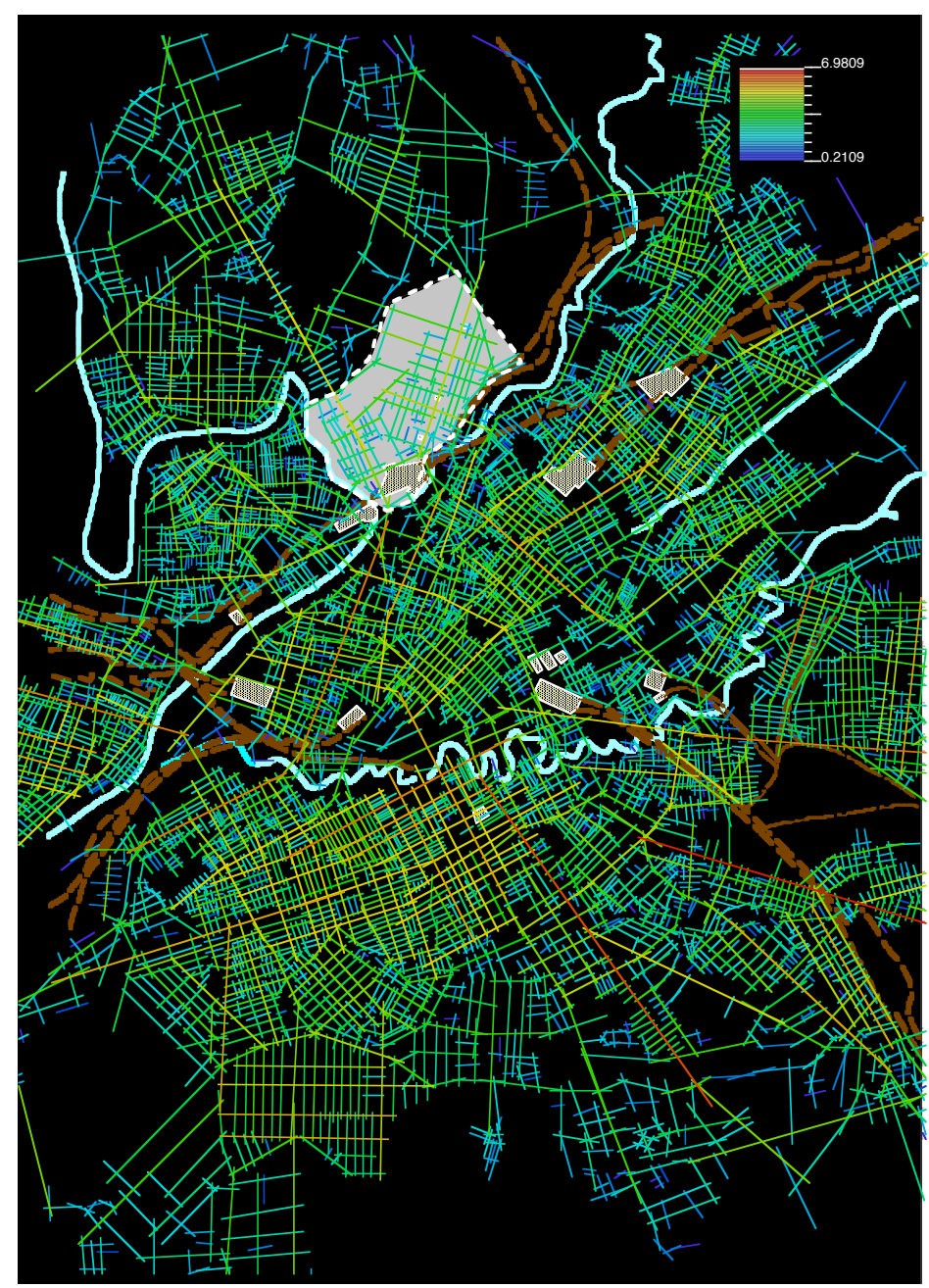

Fig. 3: Manchester axial map, local integration. 


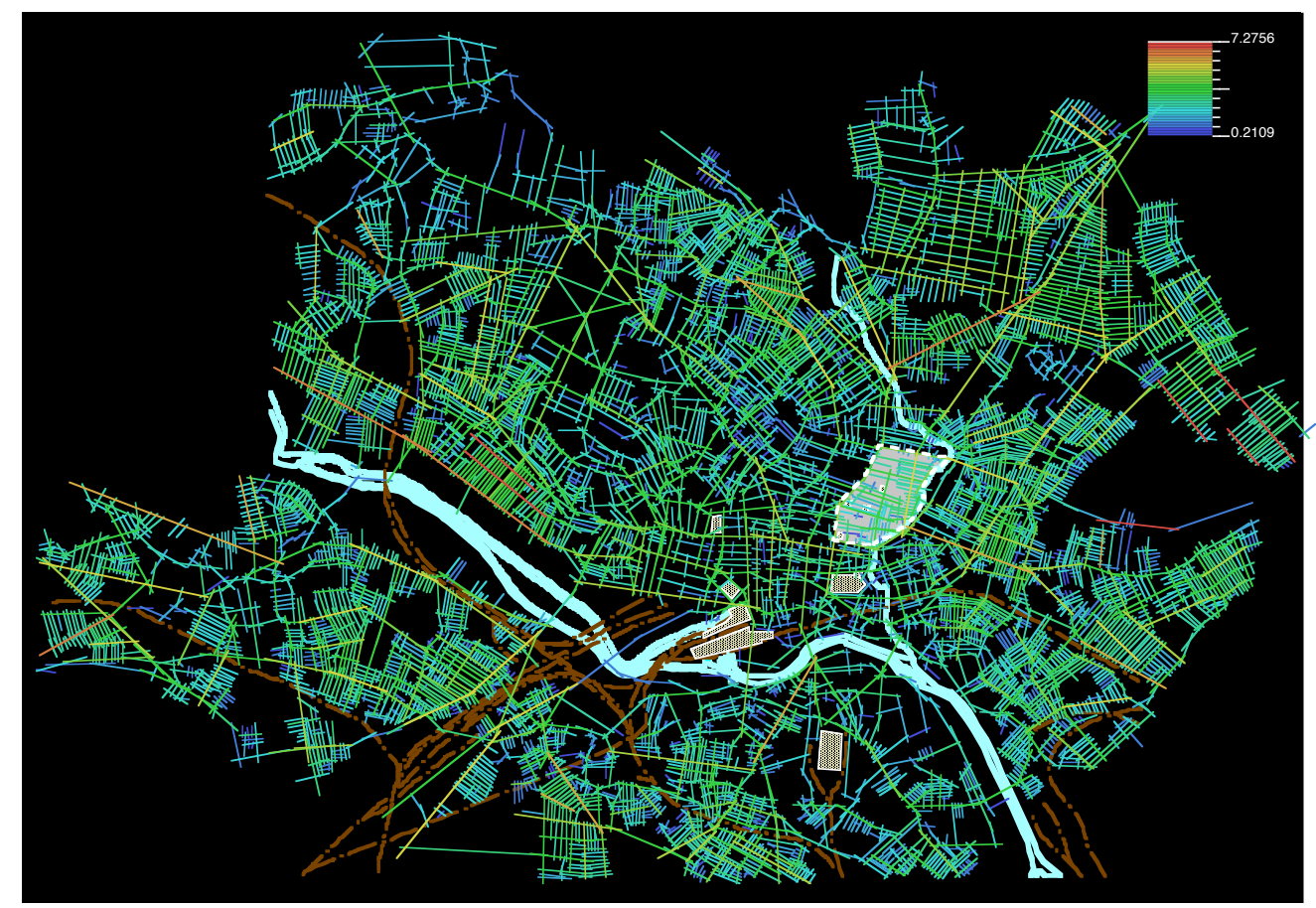

Fig. 4: Leeds axial map, local integration

The distribution of immigrant settlement was studied by calculating immigrant density for each street in the immigrant quarters. Immigrant density was measured according to the proportion of Jewish to gentile households by street. This method is the same used for the classic map of 'Jewish East London' published in Russell and Lewis (1900). The statistics on density help confirm the historical identification of Red Bank and Leylands as the immigrant quarters: the average street density within each of the areas was $44 \%$ and $38 \%$, respectively. On the other hand, once outside of the areas of initial settlement, Jews settled at lower densities (the average Jewish street density outside of Red Bank, for example, was $14 \%{ }^{9}$ ), although in the case of the more established Manchester settlement, there was still evidence of clustering in particular districts, something that was a necessity to sustain Jewish religious and cultural requirements. Indeed, as mentioned in the introduction, this lack of 'full functional integration' has been found to continue amongst English Jews in current times for similar reasons, according to Waterman and Kosmin (1987) and Valins (2003).

Statistical analysis showed that density ranged widely: from some streets with no Jewish settlement at all (only $3 / 4$ of streets in Red Bank, for example, had Jewish inhabitants), to others with $95 \%$ Jewish inhabitants. The absence of Jewish settlement in particular streets in such situations can be attributed to prejudice, but is also attributable to a desire for the Jewish immigrants to live with others from the same religious background. Contemporary studies, such as that by Peach (1996a) agree with both interpretations, although the study by Vaughan (1994) on the London immigrant quarter, in which Booth (1902) categorisations of poverty classes were compared with the Russell and Lewis map, indicated that economic situation also had an impact on the location of immigrant households, and that there was a strong relationship between poverty, the shortness of time since arrival into the country and the location of a household in the back streets of the area.

Analysis of the relationship between the density of Jewish inhabitants and local integration (see figs. 5 and 6) showed a strong reverse correspondence between density and spatial measures ${ }^{10}$. This suggests that the higher the density of Jewish settlement, the lower the spatial integration of the street in which they live, meaning that the streets with the higher rates of Jewish density were in the back streets of the area, and as density reduced, proximity to the main spatial structure went up.

\footnotetext{
${ }^{9}$ The number of inhabitants outside of Leylands in Leeds was very small, so density measures are of less relevance in this case.

${ }^{10}$ Manchester: $\mathrm{R}^{\wedge} 2=.838, \mathrm{p}<.0002$, Leeds: $\mathrm{R}^{\wedge} 2=.794, \mathrm{p}<.0005$.
} 


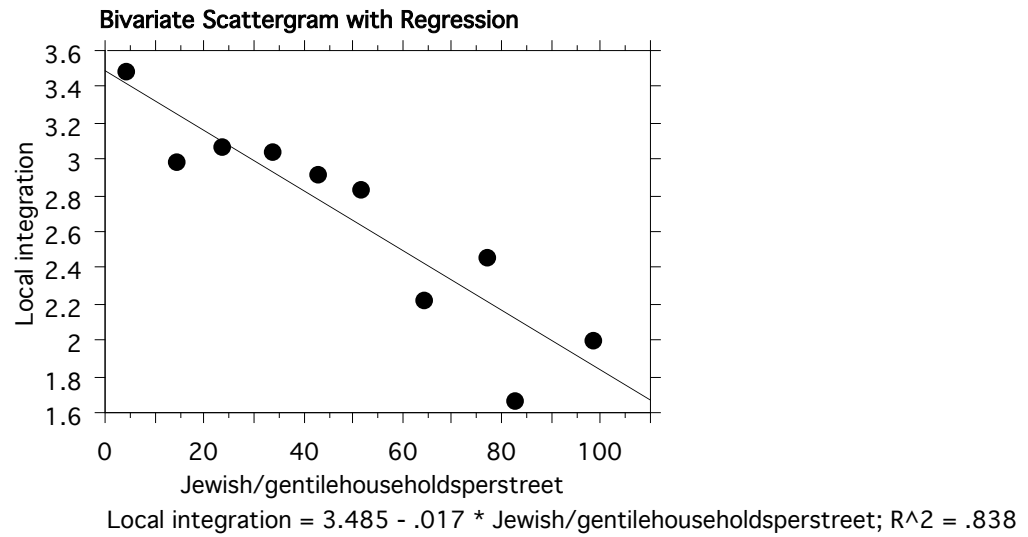

Figure 5: Regression plot of Jewish density per household against Local integration, in Red Bank

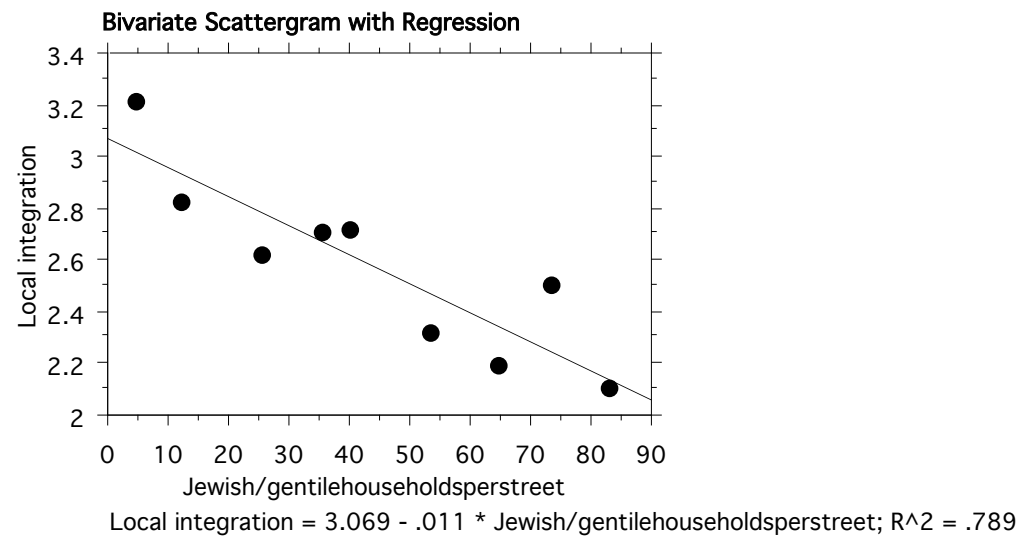

Figure 6: Regression plot of Jewish density per household against Local integration, in Leylands

This finding supports evidence that although the immigrant quarters of Red Bank and The Leylands were geographically close to the city centre, the new immigrants were living in locations which were spatially segregated due to the geography and distribution of the streets (which were cut off by the built form of the terraces and the railways and streams). Analysis of average length of time in the country (measured as the age of the eldest child born in England) for each household, plotted against the average local integration value showed that the streets with high density Jewish settlement contained Jewish households that were newer to the country and poorer. Thus, spatial analysis shows that spatial integration increased in direct proportion to length of time in the country as well as economic situation. Sources on the economics of migration have attested to there being a relationship between the latter two factors (see Godley, 2001 for example). It is notable that this result did not repeat for the gentile families born abroad and residing in Red Bank. This may suggest that these gentile families were a worse-off residual population from previous immigrant waves.

\section{Conclusions}

In both cases considered the immigrant quarters were relatively cut off from the city centre, compared with other inner-city areas. There was however a variation within each of the quarters in the spatial locations of immigrants who were new to the country and those who had been in the country for longer periods, with the latter more likely to be in spatially beneficial (less segregated) locations. As would be expected, social class defined by occupation was found to be similar for Jewish families and gentile families in the same street. However, in other measures of social class, such as household size and percentage of sharing households, the Jewish population was found to be worse off when compared with gentiles within the immigrant quarters. In addition, the tendency towards the sharing of households from the same country of origin was found to be higher amongst Jewish than gentile immigrants. Bearing in mind that the Jewish immigrants were more recent arrivals, this suggests that language or cultural co-dependence are factors more important in early stages of immigrant settlement. 
These findings suggest that since many of the factors typical of immigrant enclaves were stronger amongst Jewish immigrants, this may distinguish them from other groups. One explanation already given is the evidence found that gentile immigrants tended to have been in the country longer, and they may therefore have been less in need of mutual support. However, it is also likely that the closer ties for mutual support amongst Jewish immigrants may be due to the fact that Jewish immigrants tended to cluster in small groups known as 'chevrot' according to their town of origin and to work, pray and form benefit associations (for maternity costs, sickness and mourning) according to these small groupings. In some of these cases, as was the eastern European practice, the congregants of one synagogue might be made up of members of the same trade (Williams, 1985, p. 271-3 $\& c)$.

The incidence of endogamy amongst Jewish immigrants was found to be significantly higher than that of gentile immigrants and was not simply a case of Jews marrying other Jews, but marriage was tied back very clearly to the country of origin. This has been explained by Godley (1997), who shows that in many cases, single young males would send back home for a bride once they had established themselves financially. This goes some way to answer the question raised by Englander (1994, 63-64): 'was marriage between Polaks and Litvaks, Galizianers and Romanian immigrants, as rare as the literature suggests? We do not know... Myths about the Jewish family exist in place of systematic knowledge on marriage, household structure, kinship relations and residence patterns... Jewish family history is still in its infancy'. Jewish immigrant endogamy was shown to be very high, particularly amongst the newer immigrants of Leeds.

Analysis of occupation found significant differences between the immigrants and the indigenous population. Firstly, historical evidence that Jewish immigrants were concentrated in a narrow band of occupations was confirmed. But it was also found that Jewish immigrant occupations differed diametrically from those of their gentile neighbours. Recent studies of entrepreneurship have developed a theory of embeddedness to explain differences between immigrant groups (Light and Bonacich, 1988) and 'mixed embeddedness' - the degree in which the social and cultural networks within an ethnic group are used to advance their business activities (e.g. Barrett, Jones and McEvoy, 2001). Other studies of the immigrant economy and the over preponderance of entrepreneurship amongst such people, confirm that overseas links help strengthen this part of the economy (see Godley, 2001). An additional explanation relevant to Jewish immigrants in particular is suggested by Kershen (1995) and Smith (2004) who state that this group tended to prefer occupations which enabled sub-contracting and home working - both of which are particularly important for people requiring a more flexible or protected environment for women as well as preferring to be self-employed or to work for a co-religionist, in order to enable fulfilling religious obligations of the Sabbath and festivals. Thus, the relative segregation of the interstices of the immigrant quarters studied here may have been beneficial in sustaining the ties of mutual support within the community. Simultaneously, through the proximity and good main street links to the economic centre of each of the cities, the immigrant communities were able to make economic ties with the host community.

The findings on the high degree of Class IV and V status within the immigrant quarters, and not only for the immigrant Jews, but also the gentiles, led to the proposition that the immigrant quarter is defined as much by its poverty status as its immigrant status, particularly bearing in mind that immigrants constituted only a minority of the population of both quarters. Research elsewhere into the development of the Leeds Jewish immigrant quarter from its first stages in 1841 through to 1891 (Vaughan and Penn, 2001) has found a strong relationship between poverty and spatial segregation for both Jews and gentiles and that the social class of the general population of Leylands worsened over time. These findings put together with those reported here suggest an explanation for the formation of poverty clusters. Bearing in mind that families possessing economic and social mobility were likely to leave the area when they could, the less mobile members of the population were then left behind, creating a cycle of decline. This explanation is reinforced by the historical sources presented here that the districts in question were perceived as 'slum areas' even prior to the Jewish immigrant settlement. A similar model has been proposed by Hillier (1996), relating to the formation of modern 'sink' housing estates.

In contrast to these concerns, this paper has demonstrated the importance of spatial clustering in enabling religious, social and economic mutual support amongst immigrant groups. It has shown that the voluntary clustering of immigrants can be seen as a positive phenomenon, which seems to be a natural stage in the process of integration of immigrants into their host society. This paper suggests that the most distinctive attribute of immigrant clusters is that their spatial location and their social/economic form can have an impact on the social and economic mobility of the immigrant group. It has also emphasised the importance of the location of immigrant clusters in large cities, close to the city centre, in enabling economic activity - proposing that the spatial location of the area of initial settlement was of critical importance in its serving as a transition zone 
towards social and economic integration. These seem to be particularly relevant results, bearing in mind the current UK government tendency to prefer the "dispersal [of asylum seekers] away from 'overburdened' locales in the South East" (Hubbard, 2005, p. 56). It seems that in the contemporary city, housing choice can enable spatial clustering which avoids isolation, just as in the past spatial clustering enabled economic integration and prosperity. As Peach says in 'Good segregation, bad segregation' (1996b), immigrant clustering can have an important purpose in providing a coping mechanism for the initial stages of migration and that particularly in European cities, it ultimately enables the immigrants' descendents to move out of the area of initial settlement and to better themselves economically and socially. It remains to be seen how more recent immigrant communities develop after several generations in the UK, bearing in mind it took some 50 years for the perceived 'ghettos' of Manchester, Leeds and London to disperse to more congenial locations, but it is hoped that those groups who have been able to settle in similar patterns to those of their predecessors, will benefit from a positive trajectory "out of the ghetto".

\section{References}

AFTAB, I. (2005) The Spatial Form of Bangladeshi Community in London's East End in: A. van Nes (Ed) Proceedings of the 5th International Space Syntax Symposium, Vol.II pp. 129-144. Delft University: Delft.

ARMSTRONG, W. A. (1972) The Use of Information about Occupation, in: E.A. Wrigley (Ed) Nineteenth Century Society: essays on the use of quantitative methods for the study of social data. Cambridge: CUP.

BALLAS, D. (2004) Simulating trends in poverty and income inequality on the basis of 1991 and 2001 census data: a tale of two cities. Area, 36 (2), pp. 146-163.

BARRETT, G., JONES, T. P. and MCEVOY, D. (2001) Socio-economic and policy dimensions of the mixed embeddedness of ethnic minority business in Britain, Journal of Ethnic and Migration Studies, Special Issue on 'Immigrant entrepreneurship' edited by Robert Kloosterman and Jan Rath, 27 (2), pp. 241258.

BOOTH, C. (1902) Life and Labour of the People in London (1969 edition). New York: A.M. Kelley.

CULLING, J. (1996) Occupations: a preliminary list. Birmingham: Federation of Family History Societies (Publications) Ltd.

ENGLANDER, D. (1994) A Documentary History of Jewish Immigrants in Britain 1840-1920. Leicester: Leicester University Press.

FREEDMAN, M. (1992) Leeds Jewry: The First Hundred Years. Leeds: Murray Freedman/The Jewish Historical Society of England, Leeds.

FREEDMAN, M. (1994) Census List of Leeds Jewish Residents: 1871 (extracted and computed) Leeds: (Unpublished).

GANS, H. (1962) The Urban Villagers. New York: The Free Press.

GODLEY, A. (1997) Leaving the East End: regional mobility among East European Jews in London, 18801914, in: A. Kershen (Ed) London: The Promised Land? The Migrant Experience in a Capital City (proceedings of the Launch Conference for The Centre for the Study of Migration, 5/11/95). Aldershot, Hampshire: Ashgate Publishing, Ltd.

GODLEY, A. (2001) Jewish Immigrant Entrepreneurship in New York and London, 1880-1914. Hampshire: Palgrave Macmillan.

HER MAJESTY'S GOVERNMENT (1883) Census of England and Wales: ages, condition as to marriage and birthplaces of the people. London: Eyre and Spottiswoode.

HIGGS, E. (1996) A Clearer Sense of the Census: the Victorian censuses and historical research. London: HMSO.

HILLIER, B. (1996) Space is the Machine: a configurational theory of architecture. Cambridge: CUP.

HILLIER, B. and HANSON, J. (1984) The Social Logic of Space. Cambridge: CUP.

HILLIER, B., PENN, A., HANSON, J., GRAJEWSKI, T. and XU, J. (1993) Natural Movement: or configuration and attraction in urban pedestrian movement, Environment and Planning B: planning and design, 20, pp. 29-66.

HUBBARD, P. (2005) Accommodating Otherness: anti-asylum centre protest and the maintenance of white privilege, Transactions of the Institute of British Geographers, 30, pp. 52-65.

JACOBS, J. (1961) The Death and Life of Great American Cities. Harmondsworth, Middlesex: Penguin.

JOHNSTON, R., FORREST, J. and POULSEN, M. (2002) Are there Ethnic Enclaves/Ghettos in English Cities? Urban Studies, 39(4), pp. 591-618.

KERSHEN, A. (1995) Uniting the Tailors: Trade Unionism Amongst the Tailors of London and Leeds, 18701939. Ilford, Essex: Frank Cass \& Co.

KERSHEN, A. (Ed.) (1997) London: The Promised Land? The Migrant Experience in a Capital City 
(proceedings of the Launch Conference for The Centre for the Study of Migration, 5/11/95). Aldershot, Hampshire: Ashgate Publishing, Ltd.

LIGHT, I. H. and BONACICH, E. (1988) Immigrant entrepreneurs: Koreans in Los Angeles, 1965-1982. Berkeley: University of California Press.

LIPMAN, V. D. (1990) A History of the Jews in Britain Since 1858. Leicester: Leicester University Press.

MAKEPEACE, C. (1995) Reproductions of Old Ordnance Survey Maps: Manchester (Moss Side), 1894. Gateshead: Alan Godfrey Maps.

NASSER, N. (2004) Southall's Kaleido-scape: A study in the changing morphology of a west London suburb, Built Environment, 30(1), pp. 76-103.

NOBlE, M., SMITH, G. A. N., PENHALE, B., WRIGHT, G., DIBBEN, C., OWEN, T. and LlOYD, M. (2000) Measuring Multiple Deprivation at the Small Area Level: The Indices of Deprivation 2000London: DETR.

ORDNANCE SURVEY (1893) Map Sheet no. 104.02. Manchester: Manchester City Library.

PEACH, C. (1996a) Does Britain Have Ghettos? Transactions of the Institute of British Geographers, 21(1).

PEACH, C. (1996b) Good segregation, bad segregation, Planning Perspectives, 11, pp. 379-398.

PEACH, C. (1998) South Asian and Caribbean Ethnic Minority Housing Choice in Britain, Urban Studies, 35 (10), pp. 1657-1680.

ROBINSON, V. (1984) Asians in Britain: a study in encapsulation and marginality, in: C. Clarke, D. Ley \& C. Peach (Eds) Geography \& Ethnic Pluralism. London: Allen \& Unwin.

RUSSELL, C. and LEWIS, H. S. (1900) The Jew in London. London: Fisher Unwin.

SMITH, L. (2004) Greeners and sweaters: Jewish immigration and the cabinet-making trade in East London, 1880-1914, Jewish Historical Studies: Transactions of the Jewish Historical Society of England, 39, pp. $103-120$.

SULTAN KHAN, S. (2003) Patterns of Settlement: The South Asian Communities in London. Bartlett School of Graduate Studies. MSc Thesis. London: University College London.

THE DATA ARCHIVE [DISTRIBUTOR] (1997) 1881 Census for Great Britain (computer file). Genealogical Society of Utah - Federation of Family History Societies.

VALINS, O. (2003) Stubborn identities and the construction of socio-spatial boundaries: ultra-orthodox Jews living in contemporary Britain, Transactions of the Institute of British Geographers, 28 (2), pp. 158175.

VAUGHAN, L. (1994) A Study of the Spatial Characteristics of the Jews in London 1695 \& 1895. Bartlett School of Graduate Studies. MSc Thesis. London: University College London.

VAUGHAN, L. (1999) Clustering, Segregation and the 'Ghetto': the spatialisation of Jewish settlement in Manchester and Leeds in the 19th century. Bartlett School of Graduate Studies. PhD Thesis. London: University College London.

VAUGHAN, L. and PENN, A. (2001) The Jewish 'Ghetto' - Formation and Spatial Structure in: J. Peponis (Ed) Third International Space Syntax Symposium. Atlanta, Georgia: Georgia Institute of Technology.

WATERMAN, S. and KOSMIN, B. (1987) Ethnic Identity, Residential Concentration and Social Welfare: the Jews in London, in: P. Jackson (Ed) Race and racism: essays in social geography. London: Allen \& Unwin.

WHITE, J. (2003) Rothschild Buildings: life in an East End tenement block 1887-1920. London: Pimlico.

WILLIAMS, B. (1985) The Making of Manchester Jewry 1740-1875. Manchester: Manchester University Press.

WIRTH, L. (1928) The Ghetto (1988 edition, with a new introduction by Hasia R Diner). New Brunswick (USA) and London (UK): Transaction Publishers.

YOUNG, M. and WILLMOTT, P. (1962) Family and Kinship in East London. Harmondsworth, Middlesex: Penguin (Pelican Books). 